\title{
Reciprocal Interaction between Management Accounting and Other Management Roles
}

\author{
Huijun Zeng \\ Department of Humanities and Social Sciences, South China Agricultural University, Guangzhou, China \\ Email: huijun1004@hotmail.com
}

How to cite this paper: Zeng, H.J. (2018) Reciprocal Interaction between Management Accounting and Other Management Roles. Open Access Library Journal, 5: e4908. https://doi.org/10.4236/oalib.1104908

Received: September 14, 2018

Accepted: November 11, 2018

Published: November 14, 2018

Copyright ( 2018 by authors and Open Access Library Inc.

This work is licensed under the Creative Commons Attribution International License (CC BY 4.0).

http://creativecommons.org/licenses/by/4.0/

\begin{abstract}
The paper examines that how management accounting is integrated in other management roles which include marketing management, supply chain management and strategic human resource management. The objective of the paper sets out to analyse the reciprocal relationship between accounting and the other three management functions. It will discuss how management accounting is intertwined with other elements of business, and how each complements the other.
\end{abstract}

\section{Subject Areas}

Accounting

\section{Keywords}

Reciprocal Interaction, Management Accounting, Marketing,

Supply Chain Management, Human Resources

\section{Introduction}

Though forms of managerial accounting practices can be traced back decades, centuries even, management accounting used is regarded as a financial tool, advantageous for the financial managers. However, over the past three decades views on management accounting have changed. As Kaplan (1994) states management accounting theory has experienced a revolution in both theory and practice with the development of new innovations [1]. Through advances in information technology, more competitive markets and different organizational structures the environment for management accounting has changed (Burns \& Scapens, 2000) [2]. With the emergence of new techniques such as activity-based cost $(\mathrm{ABC})$ management and performance measurement through the balanced 
scorecard, management accounting has moved away from its former function as just a financial management tool.

In modern organizations, management accounting practices can be found throughout the organization, useful to managers from all different sectors. It allows for better informed decisions during the conception of a new product and lends itself for better understanding of the production process, both from a costing perspective, as well as a pricing one, to name a few. During the last decades a complementary relationship has been revealed between management accounting and other management accounting functions, often referred in research as the use of Edgeworth's theorem of complements (Laursen \& Foss, 2003) [3]. This essay attempts to answer the question how management accounting is implicated in other management functions. It sets out to examine the reciprocal nature between management accounting and other management functions, through the examination of several management functions; namely supply-chain, marketing and human resource management. It will set out how management accounting is intertwined with other elements of business, and how each complements the other.

\section{Supply-Chain Management}

Supply-chain management can be visualised as a loop, starting and ending at the customer (Gattorna and Walters, 1996: 12) [4]. It integrates supply and demand management both within and across companies (Council of Supply Chain Management Professionals, 2014) [5], in order to look at the business as one continuous process (Gattorna and Walters, 1996: 12) [4]. According to Seal et al. (1999) [6], especially companies incurring manufacturing costs consisting mainly out of material costs should be concerned with the management of supply chain cost as an element of overall cost management, in order to manage through control by information rather than control by doing (Gattorna and Walters, 1996: 15) [4]. Rapid developments in information technology paired with increasing physical cost of doing business have been the main drivers behind supply-chain management (Gattorna and Walters, 1996: 105) [4]. And it is this information flow that requires interactions between the management accountant and managers all through the supply-chain. Under the conditions of supply-chain management, the organizational issues are important; the application is much more effective when companies are integrated within a supply chain (Gattorna and Walters, 1996: 107) [4]. Therefore management accounting strategic objectives for supply chain extend to suppliers, customers, and any other relationships within the chain, there are cost savings available from improved vehicle utilization (Gattorna and Walters, 1996: 107) [4]. In order to gain a corporate competitive advantage, managers must improve their original organizational structure from resource allocation, management-level settings, and decision-making design to a relationship design of the supply-chain connecting upper node companies and lower node companies. For example, Ellram (1991) notes that when analyzing leveraged products, strategic products and other key 
products of the supply? Chain, management accounting is widely used [7].

Besides aligned objectives, supply-chain management has affected the tactical perspective of MA. That perspective focuses on the means by which the strategic objectives may be realized (Gattorna and Walters, 1996: 109) [4]. According to Shields (1998), the former goals of management accounting were to strengthen internal management, as well as maximize enterprise value and net cash flow through product costing, responsibility accounting, and budgeting [8]. However, these targets are often short-term, costly, quickly out-dated and ignore market risks. A highly competitive market has shaped current goals and tools. Supply-chain related management accounting extends its goal to seek value of the whole chain. Through management of the whole supply-chain internal suppliers, manufacturers, distributors and customers are involved. No single member attempts to maximize its profits at the cost of the group. Through an information loop within the supply-chain, the management accountant is able to perform supply-chain analysis, value chain analysis and programming chain analysis, helping managers to control product cost.

Besides these changes in the strategy and the tactical perspectives that are observed in management accounting when combining it with supply-chain management, the operational perspectives which concerned with the efficient operation of the supply chain is taking into consideration. Taking different industries features and marketing changes into account, managers add Supply-Chain Customer Analysis, and value chain analysis into management accounting when make decisions and design management strategy. Compared with the former measurement of management accounting, the new measurement are more specific and particular For example, when evaluating customers' satisfaction, several data such as frequency of delivery, order cycle time, reliability of delivery, flexibility in replenishment, order fulfillment accuracy and accuracy of documentation are used (Gattorna and Walters, 1996: 47) [4]. And improving the value chain, which aims to synchronize the service requirements of the customer with the flow of materials from suppliers such the apparent contradictory situation of conflicting goals of high customer service, low inventory investment and low operating costs may be balanced (or optimized) (Gattorna and Walters, 1996: 107-108) [4].

Supply-chain management has affected the use of management accounting tools in several areas, especially the objectives, target and measurement methods of the management accountant. Supply-chain management has become a new field within management accounting and control in order to fulfil the need for more comprehensive data analyses throughout the supply chain. In essence Supply-Chain management has brought the management accountant together with all different management functions along the production process to optimize it as a whole.

\section{Marketing Management}

Over the last years work within marketing and accounting have started overlap. 
Focused on the market, strategic management accounting integrates insights from marketing within a strategic management framework. Management accounting and marketing are mutually interactive during the whole process of the marketing management procedure step by step.

In order to tap market opportunities, companies should perform micro-environment and macro-environment research to establish the necessary data-based target marketing. This includes identifying specified customer profile of their needs, preference, democracies and reactions to various products and defining market anticipated response or sales. As such, the evaluation of market opportunities, which might be appropriate and profitable for the enterprise; whether full, use of existing resources of the enterprise takes advantage of its profitability; or bench-marking to see whether a company outperforms its competitors. As Roslender and Wilson (2012) mention that there is growing misconnection between market value and financial information and it leads to poor performance of firms [9]. Management accountants are required to supply data and analyses to assist marketing and management personnel to select the most suitable strategy for the enterprises marketing opportunities.

During the marketing management process, next step is to select target markets. Associated with this, the management accountant and marketing manager should concern about value-added and the cost of invested resources. A question as "Which marketing activities are valued by customers?" is raised to make decisions. Furthermore they further analyse to measure the market size and structure of the industry, and predict future market prospects.

Thirdly, the financial aspect of management accounting should be integrated into marketing strategies, specifically when looking at product pricing, packaging, service channels, advertising volume, which are based on the current and future value of the net cash flow.

During the product design phase, life-cycle costing method is required to calculate the total cost of ownership over the life span of the industrial product. It can especially apply to the marketing of industrial products, which sell for high price, but still provide long-run cost savings (Brown, 1979) [10]. After that, with the accounting data accumulated (the first step mentioned above), accountants utilize the information to build up activity-based costing (ABC) and target costing (TC) system. Including more than fifty per cent of total costs, marketing costs play a vital role in strategic cost management. On one hand, (Hennessey, 1994) suggests an outline for ABC: establish activities, assign all costs to activities, identify cost drivers and assign activity costs to products [11].

Cost additions and targeted profit will be captured through $\mathrm{ABC}$ technique, which helps marketing department's response to target costing in a short time. TC, on the other hand, is a management process that drives products to the most attractive targeted market. When TC is used, the entire value-chain should be considered. Depending on the relevant circumstances the management accountant and marketing manager derives the appropriate pricing methods to 
develop the most reasonable price. No organization or industry has the ability to price its products below their production costs indefinitely.

Finally, management accounting also plays a vital role in the implementation of marketing activities and management control over the firm. In this step, the management accountant should be involved in the feedback of marketing plans and marketing budgets, after the completion for the comprehensive enterprise budget. In the process of making a marketing performance assessment (MPA), management accounting can be calculated into income and expenses to help the marketing department to understand the extent of its feedback to achieve the set objects (Morgan, Clark and Gooner, 2002) [12]. It is necessary for accountants to tell the difference between current situations and future expectations and to analyse its cause and effect in order to help marketers to take the necessary measures.

\section{Strategic Human Resource Management}

Over the past decades Human Resource Management has undergone a change, simultaneous and similar to Management Accounting. Management accounting has moved transitionally from cost accounting towards management accounting, and subsequently to strategic management accounting (Jones, Atkinson and Lorenz, 2012: 303) [13], while HRM moved from Personnel Management to Strategic Human Resource Management. Human resources management is defined as the set of activities closely related to the management of employee coordination in an enterprise (Boxall and Purcell, 2003: 1), the management of labour and personnel (Boxall et al., 2007: 7) [14] and the combination of those to provide growth of the organization (Wilkinson, 2010 cited by Boxall and Purcell, 2010: 29) [15]. On the other hand, Armstrong (2011: 48) defines strategic human resources management as "an approach to managing people that deals with how the organization's goals will be achieved through its human resources by means of integrated human resources strategies, policies and practices" [16]. Having in mind these views it is interesting to see that management accountants are described as consultants within an organisation, providing crucial information during the formulation of human resource strategies and significant in the implementation of said decisions and strategies of the HM managers (Vedd, 2005) [17]. In the following paragraphs we will attempt to show the connection between SHRM and SMA by examining several of SHRM strategies defined by Armstrong (2011) more closely [16].

Human Capital Management Strategy is defined by Manocha (2005:28 referred by Armstrong, 2011: 175) as a process that helps enterprises find the way in which employees contribute to, and lead, company's performance [16]. Techniques such as balance scorecards developed by management accountants to measure overall performance (Kaplan, 1994) are redefined into i.e. HR scorecards [1], balance scorecards and causal links between human capital and business performance to identify and deploy the most efficient strategy (Armstrong, 2011: 175) [16]. However connecting HCM with overall performance is just a 
first connection between management accounting and HRM.

Engagement strategy concerns itself with the personal commitment an employee exhibits to the company's mission and value, ensuring employee motivation as well as social welfare in the company, while reward strategy focuses on the recognition and recompenses of employees. If an organisation is able to efficiently engage its employees, "fairly" rewarding employees through the use of appropriate performance targets, it will improve the working environment and worker's moral (Armstrong, 2011: 201) [16], which in turn will contribute to customer satisfaction and overall performance (Kouhy, et al., 2009) [18]. In order to set appropriate performance targets, which are achievable for the employee with reasonable exertion, the HR Manager will have to cooperate with the management accountant. It is important to set goals sufficiently within the grasp of an employee, while simultaneously challenging the employee to develop further. At the same time it is important provide employees with recognition for their achievements, rewarding for their performance, encouraging them to continue to perform well. Studies have linked employees' well-being, job satisfaction and motivation to customer satisfaction as well as overall performance (Kouhy, et al., 2009) [18].

To empower employees to take responsibility for their work and pride in their work, employers should not just engage and reward employees; they should nurture talent within their human capital. A learning and development strategy focuses on actions such as employee learning, continual training and development to enhance the ability level of employees, affecting company's performance positively (Armstrong, 2011: 249-253) [16]. In a meanwhile a resourcing strategy combines talent management and flexibility, to enhance employees' ability, thinking and actions, while always keeping actual business performance in mind. During the preparation of company budgets, management accountants need to provide for elements such as training and education to ensure company performance on a longer term. Although the costs of employee training might not be directly linked to an end product, it can be linked to employee satisfaction, and thus as stated earlier to customer satisfaction and overall firm performance.

In the end it comes down to employee relations. One can use management accounting techniques to set performance targets and reward structures to help Human Resource Managers to create a pleasant work environment, satisfied, engaged, challenged and motivated workers. In return this human capital will lead to innovation, customer satisfaction and overall performance. Though they are different forms of management, all are needed in the current economy that focuses highly on strategic decision making.

\section{Conclusions}

This paper sets out to provide evidence about the reciprocal relationship between management accounting and other management functions, specifically examine and provide evidence of the interactions of management accounting 
with supply chain management, marketing management and strategic human resources management. All the findings point towards the same direction. Management accounting contributes and cooperates with all three functions in order to make sure a company's objectives are achieved. First of all, management accounting helps supply chain management in means of objectives, target and measurement methods to provide information about the strategies than need to be undertaken or that will be undertaken. Management accounting helps improve the strategic marketing planning and control by providing data about the markets, supply and demand figures, proper activity based pricing, the firm's position in relation to their rivals and market planning. Last but not least, as far as strategic human resources management is concerned, management accounting provides the means to improve employee relations and coordination.

Together they make sure that they are aware of the firm's objectives and strategies, by working towards achieving such goals. In other words, the introduction of balanced scorecards, and proper rewards for high achieving employees and feedback of employee contribution development are included in the management accounting process to make sure that labour is working properly in line with the firm's goals. The results of this essay exemplify the change in management accounting as referenced by Burns \& Scapens (1999) [2]. No one can forecast the future, what changes it might hold in store; only these changes, like past changes, will occur due to the progressive nature of its environment.

\section{Conflicts of Interest}

The author declares no conflicts of interest regarding the publication of this paper.

\section{References}

[1] Kaplan, R. (1994) Management Accounting (1984-1994): Development of New Practice and Theory. Management Accounting Research, 5, 247-260. https://doi.org/10.1006/mare.1994.1015

[2] Burns, J. and Scapens, R. (2000) Conceptualizing Management Accounting Change: An Institutional Framework. Management Accounting Research, 11, 3-25. https://doi.org/10.1006/mare.1999.0119

[3] Laursen, K. (2003) New Human Resource Management Practices, Complementarities and the Impact on Innovation Performance. Cambridge Journal of Economics, 27, 243-263. https://doi.org/10.1093/cje/27.2.243

[4] Gattorna, J. and Walters, D. (1996) Managing the Supply Chain. Macmillan Business, Basingstoke. https://doi.org/10.1007/978-1-349-24841-4

[5] CSCMP (2014) CSCMP Supply Chain Management. Council of Supply Chain Management Professionals. http://crossref.org/SimpleTextQuery

[6] Seal, W., Cullen, J., Dunlop, A., Berry, T. and Ahmed, M. (1999) Enacting a European Supply Chain: A Case Study on the Role of Management Accounting. Management Accounting Research, 10, 303-322. https://doi.org/10.1006/mare.1999.0105

[7] Ellram, L. (1991) Supply-Chain Management: The Industrial Organisation Perspective. International Journal of Physical Distribution \& Logistics Management, 21, 
13-22. https://doi.org/10.1108/09600039110137082

[8] Shields, M. (1998) Management Accounting Practices in Europe: A Perspective from the States. Management Accounting Research, 9, 501-513. https://doi.org/10.1006/mare.1998.0081

[9] Roslender, R. and Wilson, R.M.S. (2012) The Marketing/Accounting Interface. Journal of Marketing Management, 24, 661-668.

[10] Brown, R. (1979) A New Marketing Tool: Life-Cycle Costing. Industrial Marketing Management, 8, 109-113. https://doi.org/10.1016/0019-8501(79)90050-6

[11] Hennessey, S. (1994) Activity-Based Costing for Marketing and Manufacturing. Journal of Business Research, 30, 283.

[12] Morgan, N., Clark, B. and Gooner, R. (2002) Marketing Productivity, Marketing Audits, and Systems for Marketing Performance Assessment: Integrating Multiple Perspectives. Journal of Business Research, 55, 363-375. https://doi.org/10.1016/S0148-2963(00)00162-4

[13] Jones, T., Atkinson, H. and Lorenz, A. (2012) Strategic Managerial Accounting. Goodfellow Publishers, Oxford.

[14] Boxall, P., Purcell, J. and Wright, P. (2007) The Oxford Handbook of Human Resource Management. Oxford University Press, Oxford.

[15] Boxall, P. and Purcell, J. (2010) An HRM Perspective on Employee Participation. In: Wilkinson, A., Gollan, P.J., Marchington, M. and Lewins, D., Eds., The Oxford Handbook of Participation in Organizations, Oxford University Press, Oxford, 129-151.

[16] Armstrong, M. and Armstrong, M. (2011) Armstrong's Handbook of Strategic Human Resource Management. Kogan Page, London.

[17] Vedd, R. (2005) Management Accounting and Strategic Human Resource Management: A UK/Canadian Comparative Analysis. Journal of Applied Accounting Research, 6, 90-120. https://doi.org/10.1108/96754260180001029

[18] Kouhy, R., Vedd, R., Yoshikawa, T. and Innes, J. (2009) Human Resource Policies, Management Accounting and Organisational Performance. Journal of Human Resource Costing \& Accounting, 13, 245-263.

https://doi.org/10.1108/14013380910995520 